\title{
Successes and challenges with retroviral enzymes
}

(aka: Adventures with the Wlodawer laboratory)

\section{Anna Marie (Ann) Skalka}

\section{Mark D. Andrake}

\section{Richard A. Katz}

Fox Chase Cancer Center, Institute for Cancer Research, Temple University Health System, Philadelphia PA, USA

Fox Chase Cancer Center, Institute for Cancer Research, Temple University Health System, Philadelphia PA, USA; e-mail: AM_Skalka@ fccc.edu

Received: May 26, 2016

Accepted: May 27, 2016

\section{ABSTRACT}

Collaborations between the Wlodawer and Skalka laboratories have covered a period of almost 30 years. During that time our groups have co-authored 18 publications, including several much cited journal articles, book chapters, and scholarly reviews. It has therefore been most rewarding for us to share enthusiasm, insights, and expertise with our Frederick colleagues over the years, and also to enjoy lasting friendships.

We first met Alex Wlodawer through an ongoing collaboration with Jonathan Leis, who was then at Case Western Reserve University in Cleveland Ohio. Our work with the Leis laboratory was based on a shared interest in the three enzymes that are encoded in all retroviral genomes: reverse transcriptase, integrase, and protease. Ann and Jonathan also enjoyed a special kinship because they were both trained in biochemistry by Jerry Hurwitz at the Albert Einstein College of Medicine (although at different times). Initial collaborative studies, which began in the early 1980's, focused on enzymes of the well-characterized avian sarcoma/leucosis viruses (ASLVs). Knowledge gained with the avian virus proteins proved to be quite valuable, when the world-wide ravages of another retrovirus, HIV, created a new sense of urgency in the field, demanding the attention of many retrovirologists. Together with NIH colleagues, in 1986 Ann co-authored a paper that described mapping of the protease gene in HIV-1 (then still known as HTLV-III) [1]. This work was especially significant because it established the HIV protease as a prime target for anti-viral drug development. Studies of both ASV and HIV proteases continued in the Skalka laboratory, then at the Roche Institute of Molecular Biology. To facilitate analyses of enzyme mechanism, a simple but powerful assay for enzyme activity was developed, based on the use of small peptide substrates and purified proteases [2]. It was clear to us, and to the pharma interests at Hoffmann La Roche, that such an assay could be used to screen for HIV protease inhibitors. Indeed, Leis actually provided Roche with a large sample of purified retroviral protease with which to begin their drug development efforts. However, while a simple, high-throughput biochemical assay was crucial for drug screening, it was also apparent that detailed knowledge of the structure of the enzyme would be required for rational drug design. The opportunity for us to contribute to the latter goal came from a 1987 meeting between Jonathan and Alex, which occurred just before our laboratory moved from the Roche Institute to the Fox Chase Cancer Center, where Ann was to become Scientific Director.

Our three-way collaborative efforts focused initially on the well-characterized protease of ASV. Jonathan was able to provide sufficient amounts of the purified enzyme for crystallography in Alex's laboratory, while we conducted biochemical analyses. To everyone's delight, it was not too long before a crystal structure of this very obliging protein was solved in Alex's laboratory [3]. The results revealed a dimeric structure similar to that of the well-known, monomeric cellular aspartic proteases. The fact that the cellular enzymes were already subjects for drug development was a substantial advantage for anti-viral drug discovery. The ASV crystal structure allowed Irene Weber and others in the Wlodawer laboratory to rapidly model the HIV-1 protease [4]. The accuracy of that model was confirmed by later crystal structures of the HIV-1 enzyme obtained in Alex's laboratory, as well as by others. Determination of the ASV and HIV protease structures comprised a major scientific breakthrough in the field, duly noted by prominent display on the cover of the 1989 "RNA Tumor Virus" Meeting at Cold Spring Harbor (Fig. 1). To elucidate details of enzyme-substrate interactions, our groups then conducted a series of mutational analyses. Results from these studies helped to delineate the basis for the substrate specificities of these proteins $[5,6]$. As noted in the Wlodawer group's recent protease "reminiscence" article [7]: "Determinations of only a very few protein structures had consequences compara- 


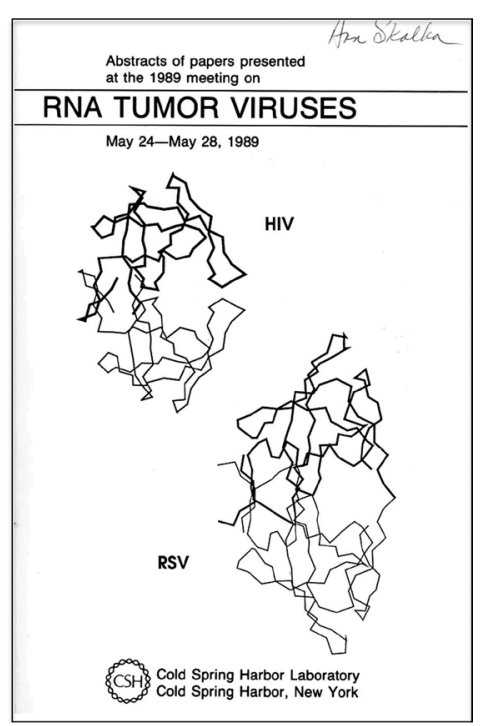

Figure 1. Abstract Book Cover, 1989 Cold Spring Harbor RNA Tumor Virus Meeting. Alex Wlodawer provided the alpha carbon backbone representations of both the RSV and HIV protease structures for this cover. In each dimeric protease protein, one monomer is shown by a thin line and the second with a thick line.

ble to the impact exerted by the structure of the protease encoded by HIV-1...". Indeed, the HIV protease structure was to become the textbook standard for successful rational design of inhibitors and, eventually, led to the availability of some of the most powerful drugs for the treatment of AIDS.

The Leis and Skalka laboratories had also been collaborating on ASV integrase, or pp32 as it was then known. This enzyme had been discovered as an endonuclease, and together we showed that it could cleave viral DNA ends in so-called "LTR-LTR DNA circle junctions" in vitro. Work by others in the field, using MLV complexes isolated from infected cells, later implicated linear retroviral DNA as the immediate precursor of integrated DNA in vivo. This inspired our efforts to determine if integrase could process the linear ends of viral DNA. Following Ann's suggestion to use short synthetic substrates with sequence corresponding to the ends of viral DNA, Michael Katzman in the Leis lab showed that ASV integrase activity could, indeed, nick cognate ASV DNA at the appropriate site [8]. Richard Katz in the Skalka group next showed that purified ASV integrase was both necessary and sufficient for joining the nicked viral DNA ends to host DNA [9]. These findings launched a new era in the Wlodawer/Skalka/Leis collaborations, as we now had available: copious supplies of enzymes purified from E. coli for structural analysis, relevant substrates that were acted upon in vitro, and simple biochemical assays to support our studies. Analysis of the structure and function of the retroviral integrases using site-directed mutagenesis became a major focus in the Skalka laboratory in the ensuing years and many concepts and findings were discussed at our joint "Integrase Jamboree Meetings" held alternatively at the Fox Chase Cancer Center in Philadelphia and NCI, Frederick. During these years of concerted efforts, teleconferences and meetings of our groups were frequent. Many meetings found Jonathan, Alex, Ann, and their lab members, brain-storming around tables, at lunches, and at dinners, conjuring up new conditions and approaches for our experiments.
Shortly after our integrase collaboration was initiated, Joe Mack, a postdoctoral fellow from Alex's laboratory, came to the Skalka laboratory as a visiting scientist to learn how to purify integrase (Fig. 2B). Although a neophyte in biochemistry, Joe was an expert in protein sequence analysis, at a time when tools for such analyses were crude and difficult to manage. By aligning the amino acid sequences of retroviral integrases that were available at the time, he rapidly delineated three conserved domains in these proteins. Furthermore, by comparing the retroviral sequences with those of transposases from a variety of transposable elements, Joe also found a region of strong conservation in the central core domain of integrase. Two invariant acidic residues in this region, exactly 35 amino acids apart in all integrases, seemed likely candidates for binding of the metal cofactor known to be required for catalysis. Joe Kulkosky, a postdoctoral associate in the Skalka lab, subsequently identified a third invariant acidic residue in the core domain (Fig. 2A). Our subsequent site-directed mutagenesis confirmed that all three acidic residues, comprising what we called the D, $\mathrm{D}(35) \mathrm{E}$ motif (or simply DDE), are essential for catalysis by the retroviral integrases [10].

The development of convenient in vitro assays to measure the enzymatic activities of integrase was a pivotal contribution to the field from our collaboration $[8,9,11]$. These assays, and derivatives thereof, were subsequently employed by all integrase researchers, not only to purify and analyze these proteins, but also to screen for inhibitors. Thanks to such screening, HIV integrase inhibitors were available in the clinic for the treatment of AIDS, long before the molecular details of their interactions with the protein were known. Use of the assays provided important insights into both the structure and mechanism of integrase. The existence of three conserved domains was confirmed, and roles in catalysis were elucidated for each domain. Our biochemical and mutagenesis studies also revealed that a single active site in the central catalytic core domain catalyzes the two biochemically distinct activities of the enzyme (processing viral DNA ends and joining them to a host DNA target), and that the protein functions as a multimer $[10,12,13]$.

The first major efforts of crystallography focused on the catalytic core domain of ASV integrase. Although we knew the central location of the active site, we had no idea where the structural boundaries for this domain might lie. During one of their many discussions, Joe Mack suggested to Richard Katz that an unbiased, empirical approach could be used whereby stability in E. coli would signify proper folding of the catalytic domain. By engineering a series of C-terminal deletions Katz found that the 1-207 fragment, with 79 residues removed from the terminus of the protein, was the most stable product. Then, he engineered a construct with a deletion from the N-terminus to produce the isolated central, catalytic core domain of ASV integrase, corresponding to amino acid residues 52-207. Happily, this isolated domain crystallized. Joe Mack's alignments were subsequently linked to a 3D structure solved by Gregor Bujacz and others in the Wlodawer laboratory at $1.7 \AA$ resolution (see a similar structure solved later with metal bound in Fig. 3) [14]. Although not the first retroviral integrase core domain crys- 


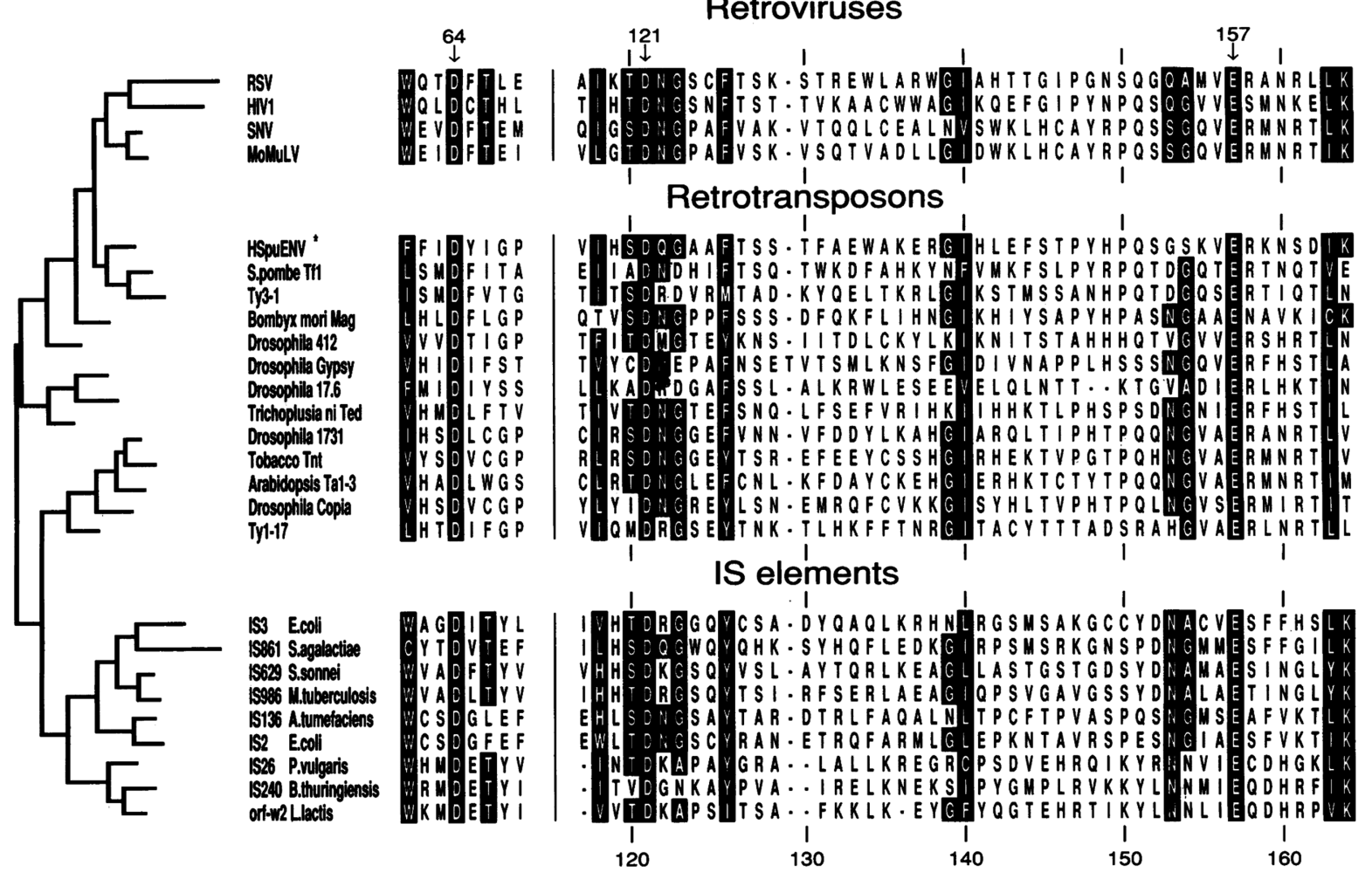

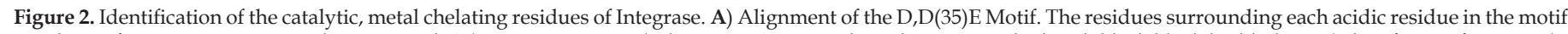

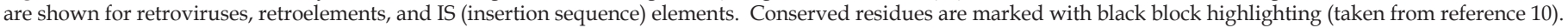

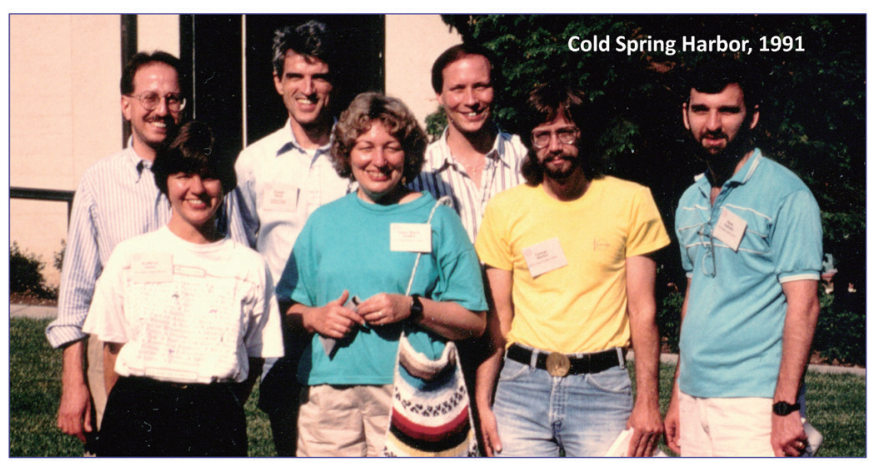

Figure 2. B) Skalka Group with Joe Mack at the Cold Spring Harbor RNA Tumor Virus Meeting of 1991. Back row: Richard (Rich) Katz, Joe Mack, Joseph (Joe) Kulkosky. Front row: Katherine (Kathy) Jones, Anna Marie (Ann) Skalka, George Merkel, Mark Andrake.

tal structure reported, this relatively high resolution ASV structure was published only a few months after the $2.5-\AA$ resolution structure of the isolated core domain of HIV integrase was reported by David Davies' group at NIH [15]. Comparison of the two integrase catalytic core domains revealed highly similar folding and topology, and established that these enzymes are members of the ribonuclease $\mathrm{H}$ family of polynucleotide transferases. The ASV core domain structure proved to be most informative, as it was in a more native conformation than that of HIV. The metal-binding site was found to be pre-existing in the ASV core domain, indicating that the constellation of the essential acidic residues (DDE) was likely to represent a catalytically competent configuration. Through the skillful efforts of Grzegorz, and Jacek Lubkowski, together with Alex and others in his group, the first ASV integrase core domain structure was soon followed by additional high-resolution structures of the domain in the presence of divalent cations [16] (Fig. 4), with a bound inhibitor of HIV-1 integrase [17], and with active site residue substitutions [17-19]. Among the metal bound structures, two cations $\left(\mathrm{Zn}^{2+}\right.$ as well as $\left.\mathrm{Cd}^{2+}\right)$ were found in the active site. Although these metals are not physiologically relevant for catalysis, they provided direct proof of the ability of the active site to coordinate two metal ions (Fig. 4). These results provided strong evidence to support

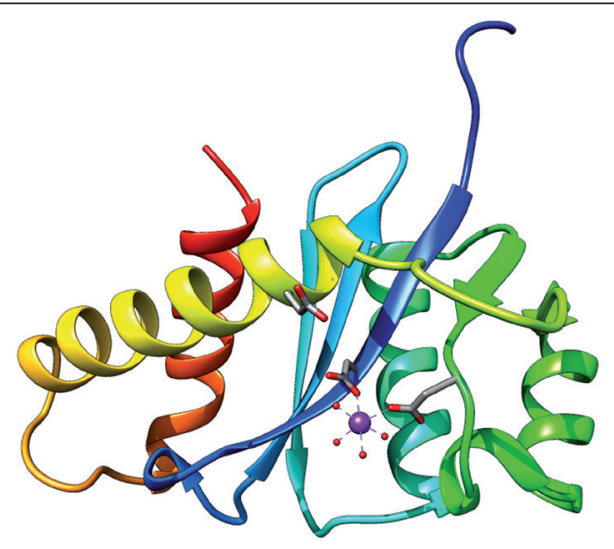

Figure 3. Structure of the catalytic core domain of ASV integrase. Shown is the 2.0 A structure of the ASV integrase catalytic core domain solved in Alex's lab by Gregor Bujacz (PDB code 1VSF). It was the first catalytic core structure of an integrase with $\mathrm{Mn}^{2+}$ metal bound (purple sphere) and with associated waters (red balls) to complete an octahedral ligand configuration with oxygen atoms from D64 and D121 of the DDE motif shown in stick representation. Given the precedent from other integrase structures, the second divalent metal between D64 and E157 would be seen only in the presence of substrate DNA. The ribbon trace is rainbow colored from blue at the $\mathrm{N}$-terminus to red at the $\mathrm{C}$-terminus. 


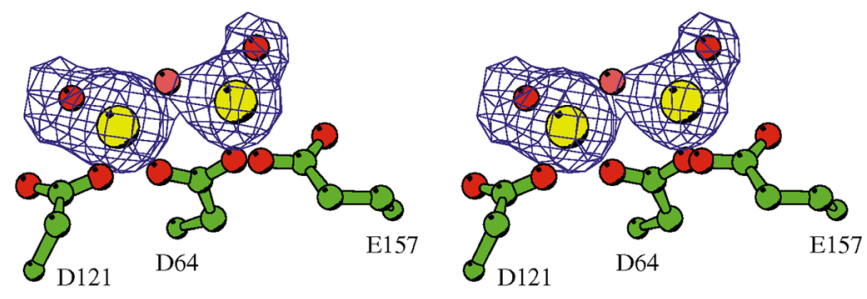

Figure 4. Acidic DDE residues bound to divalent metals. Stereo figure taken from reference 16, (Bujacz, 1997) shows ASV residues D64, D121, and E157 coordinating two bound $\mathrm{Zn}^{2+}$ ions (yellow spheres) and some nearby ordered water molecules (red spheres). Coordinates are from the PDB code 1VSH.

a two-metal mechanism of polynucleotidyl-transferase activity for this class of enzymes [20,21]. This feature was an important focal point for the development of active site inhibitors of HIV integrase [22]. Indeed, chelation of the two metal cofactors in the active site is a property of all HIV integrase inhibitors currently in clinical use.

Another feature noted in these, and subsequent crystallographic analyses, had a profound impact on ideas about mechanism. The catalytic core domains of all retroviral integrases analyzed formed tight dimers when crystallized alone or in two-domain fragments that included either the $\mathrm{N}$ - or C-terminal domain (NTD and CTD, respectively). In these core domain dimers, the catalytic centers face outward and in opposite directions. Moreover, the active sites were found to be too far apart to account for the two joining reactions that occur during integration into host DNA. This feature, together with independent biochemical evidence from our laboratory and others, implied that the integrases must function as a higher order multimer, potentially as a dimer of dimers. Although the catalytic core domains were presumed to play a key role in such dimerization, at one of our "IN Jamborees," Mark Andrake presented data showing that the CTDs are critical for integrase multimerization. As discussed below, the significance of his results, which were published shortly thereafter [23], would become apparent only years later.

Our success with the catalytic core domain provided strong incentive to try for crystal structure determination of full-length integrase. Unfortunately, the full-length
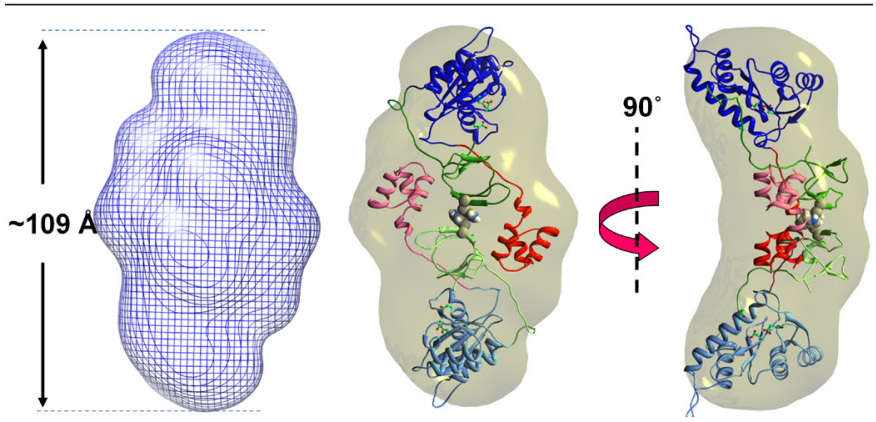

Figure 5. Architecture of the ASV reaching dimer. Left: Small Angle X-ray Scattering (SAXS) shape modeling of the reaching dimer (taken from reference [24]). Center and right: fitting of monomeric domains within the SAXS envelope based on contacts determined from cross-linking and mass spectrometry experiments. Catalytic core domains are shown in blue, N-terminal domains in red and C-terminal domains in green. One monomer is shown in primary colors and the second in slightly muted colors. protein was to be a much tougher candidate for crystallography than we had anticipated. Success was to elude us, despite heroic efforts on the part of George Merkel in the Skalka laboratory, who produced what seemed like bucket-loads of proteins for multiple trials set up by Jerry Alexandratos in Alex's lab. Part of the difficulty was due to the fact that both ASV and HIV integrase have limited solubility. The enzymes are also somewhat "floppy" owing to the presence of long flexible linkers that separate the three domains, and the full-length proteins form a variety of multimers in solution. Nevertheless, because hope springs eternal, many grams of our ASV and HIV integrase proteins were sacrificed to "Crystallization Tray Gods" in the years that followed. Although in some cases tantalizing microcrystals were observed, an atomic structure of the full-length proteins was not to be had by us (or others) in the field for some time.

Unwilling to be dissuaded from reaching for the gold ring, in the years from 2006 to 2010 Mark Andrake pursued another approach for structural analysis, small angle X-ray scattering (SAXS). This low-resolution method can reveal the shapes of monodispersed proteins in solution. By combining the data from SAXS with available knowledge of the atomic structures of the isolated domains of the integrases, the relative positions of domains could be assigned. This strategy, combined with proximity data from amino acid cross-linking and mass spectrometry analysis, allowed Mark and postdoctoral fellow, Ravi Bojja, to build credible models of the ASV and HIV integrase proteins as they exist in solution, in the absence of DNA substrates. Our first glimpse of the structure of full-length ASV integrase provided some fascinating surprises [24]. The first surprise was that relative positions of the NTD and CTD domains with respect to the core domain was opposite to what had been expected from the crystal structures of the two-domain fragments. The second surprise was that the shape and architecture deduced for the ASV integrase dimer were totally inconsistent with a model that had been derived from superimposition of the core domain dimers in two-domain crystal structures. Our analyses showed that the ASV integrase dimer was formed by interactions between two CTDs (as predicted by Mark's earlier work) and by the NTD in one monomer interacting with the core domain and CTD of the other, in a conformation that we called a "reaching dimer" (Fig. 5). Most importantly, in this full-length dimer the core domains do not interact, indeed they are at distal ends of the structure. Similar studies with HIV integrase revealed that both the reaching dimers and dimers formed by core domain interactions can be formed by this enzyme in solution [25].

Our discovery of this unsuspected reaching dimer conformation coincided with the publication by Cherepanov and colleagues of the crystal structure of the prototype foamy virus (PFV) integrase in complex with viral DNA [26]. In this structure, called an intasome, the PFV integrase assembles as a tetramer. However, DNA binding and catalysis takes place solely in an "inner" dimer, which is arranged in a conformation similar to a reaching dimer. It was therefore most satisfying to learn that our solution structures of full-length 


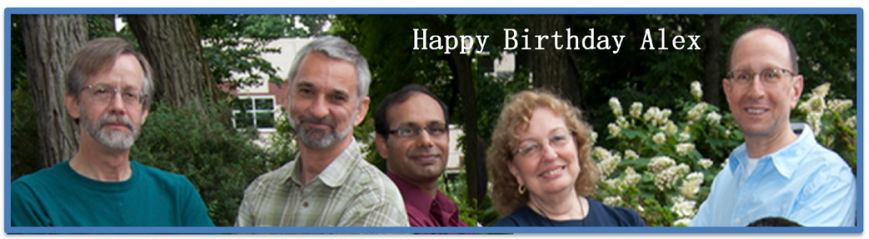

Figure 6. Happy Birthday Alex! From left to right: George Merkel, Mark Andrake, Ravi Bojja, Ann Skalka, Rich Katz.

ASV and HIV integrase had revealed an assembly that is relevant to enzyme function.

The long awaited crystal structure of full-length ASV integrase, complexed with DNA substrates, was reported in February of this year by Hideki Aihara in collaboration with Duane Grandgennet [27]. This $3.8 \AA$ resolution structure also revealed some surprises. The ASV intasome contains an inner dimer that binds and acts upon the DNA substrates, analogous to the inner dimer of the PFV intasome. However, the ASV assembly includes eight integrase protomers, rather than four as with PFV. In addition, the "extra" protomers in the ASV intasome are seen to contribute to DNA binding. A cryo-EM structure of the mammary tumor virus (MMTV) intasome has also recently revealed an integrase octamer. Interestingly, the protomer arrangement in the MMTV octamer is distinct from that in the ASV octamer [28]. It therefore seems apparent that different retroviruses can manage to accomplish the same endpoint in different ways. These findings cast some doubt on the credibility of models of the HIV intasome that are built from that of PFV. We noted with some satisfaction however that several points of contact between integrase and viral DNA in the ASV intasome had actually been identified earlier in cross-linking experiments and structure analyses conducted with the Frederick group: Alex, Elena Peletskaya, Alex Kogan, and Alla Gustchina [29]. The variety of possible assemblies of retroviral integrase revealed in the PFV, ASV, MMTV, and other structural analyses, indicate that there is much more to be learned about these proteins in the future. While each step in these analyses bring us closer to a complete picture, it seems likely that more surprises are in store for those of us that remain in the hunt.

The almost 30-year collaboration of our laboratory with the Wlodawer group clearly has been most fruitful. Together we have made numerous contributions to an understanding of the structure and function of both the retroviral proteases and integrases. We have had the satisfaction of knowing that such knowledge not only increased the scientific base of our field but also contributed to the development of drugs to treat those afflicted with HIV-AIDS. In his supervision of all these and many other structural studies, Alex always displayed a keen sense of the productive avenues to pursue together, and his characteristic "dry" sense of humor encouraged us to overcome many challenges together along the way. During this time we have also enjoyed the most collegial of interactions with our Frederick colleagues, including the warm home hospitality extended by Alex and Alla. We are therefore delighted to have this opportunity to share reminiscences and to extend our hearty congratula- tions to Alex on the occasion of his birthday, in recognition of his many outstanding achievements (Fig. 6).

\section{REFERENCES}

1. Kramer RA, Schaber MD, Skalka AM, Ganguly K, Wong-Staal F, Reddy EP (1986) HTLV-III gag protein is processed in yeast cells by the virus pol-protease. Science 231: 1580-1584

2. Kotler M, Katz RA, Danho W, Leis J, Skalka AM (1988) Synthetic peptides as substrates and inhibitors of a retroviral protease. Proc Natl Acad Sci USA 85: 4185-4189

3. Miller M, Jaskolski M, Rao JK, Leis J, Wlodawer A (1989) Crystal structure of a retroviral protease proves relationship to aspartic protease family. Nature 337: 576-579

4. Weber IT, Miller M, Jaskolski M, Leis J, Skalka AM, Wlodawer A (1989) Molecular modeling of the HIV-1 protease and its substrate binding site. Science 243: 928-931

5. Grinde B, Cameron CE, Leis J, Weber IT, Wlodawer A, Burstein H, Bizub D, Skalka AM (1992) Mutations that alter the activity of the Rous sarcoma virus protease. J Biol Chem 267: 9481-9490

6. Grinde B, Cameron CE, Leis J, Weber IT, Wlodawer A, Burstein H, Skalka AM (1992) Analysis of substrate interactions of the Rous sarcoma virus wild type and mutant proteases and human immunodeficiency virus-1 protease using a set of systematically altered peptide substrates. J Biol Chem 267: 9491-9498

7. Jaskolski M, Miller M, Mohana Rao JK, Gustchina A, Wlodawer A (2015) Elucidation of the structure of retroviral proteases: a reminiscence. FEBS J 282: 4059-4066

8. Katzman M, Katz RA, Skalka AM, Leis J (1989) The avian retroviral integration protein cleaves the terminal sequences of linear viral DNA at the in vivo sites of integration. J Virol 63: 5319-5327

9. Katz RA, Merkel G, Kulkosky J, Leis J, Skalka AM (1990) The avian retroviral IN protein is both necessary and sufficient for integrative recombination in vitro. Cell 63: 87-95

10. Kulkosky J, Jones KS, Katz RA, Mack JP, Skalka AM (1992) Residues critical for retroviral integrative recombination in a region that is highly conserved among retroviral/retrotransposon integrases and bacterial insertion sequence transposases. Mol Cell Biol 12: 2331-2338

11. Merkel G, Andrake MD, Ramcharan J, Skalka AM (2009) Oligonucleotide-based assays for integrase activity. Methods 47: 243-248

12. Jones KS, Coleman J, Merkel GW, Laue TM, Skalka AM (1992) Retroviral integrase functions as a multimer and can turn over catalytically. J Biol Chem 267: 16037-16040

13. Kulkosky J, Katz RA, Merkel G, Skalka AM (1995) Activities and substrate specificity of the evolutionarily conserved central domain of retroviral integrase. Virology 206: 448-456

14. Bujacz G, Jaskolski M, Alexandratos J, Wlodawer A, Merkel G, Katz RA, Skalka AM (1995) High-resolution structure of the catalytic domain of avian sarcoma virus integrase. J Mol Biol 253: 333-346

15. Dyda F, Hickman AB, Jenkins TM, Engelman A, Craigie R, Davies DR (1994) Crystal structure of the catalytic domain of HIV-1 integrase: similarity to other polynucleotidyl transferases. Science 266: 1981-1986

16. Bujacz G, Alexandratos J, Wlodawer A, Merkel G, Andrake M, Katz RA, Skalka AM (1997) Binding of different divalent cations to the active site of avian sarcoma virus integrase and their effects on enzymatic activity. J Biol Chem 272: 18161-18168

17. Lubkowski J, Yang F, Alexandratos J, Wlodawer A, Zhao H, Burke TR, Jr., Neamati N, Pommier Y, Merkel G, Skalka AM (1998) Structure of the catalytic domain of avian sarcoma virus integrase with a bound HIV-1 integrase-targeted inhibitor. Proc Natl Acad Sci USA 95: 48314836

18. Lubkowski J, Dauter Z, Yang F, Alexandratos J, Merkel G, Skalka AM, Wlodawer A (1999) Atomic resolution structures of the core domain of avian sarcoma virus integrase and its D64N mutant. Biochemistry 38: 13512-13522

19. Lubkowski J, Yang F, Alexandratos J, Merkel G, Katz RA, Gravuer K, Skalka AM, Wlodawer A (1998) Structural basis for inactivating mu- 
tations and $\mathrm{pH}$-dependent activity of avian sarcoma virus integrase. J Biol Chem 273: 32685-32689

20. Beese LS, Steitz TA (1991) Structural basis for the 3'-5' exonuclease activity of Escherichia coli DNA polymerase I: a two metal ion mechanism. EMBO J 10: 25-33

21. Davies JF, Hostomska Z, Hostomsky Z, Jordan SR, Matthews DA (1991) Crystal structure of the ribonuclease H domain of HIV-1 reverse transcriptase. Science 252: 88-95

22. Neamati N, Lin Z, Karki RG, Orr A, Cowansage K, Strumberg D, Pais GC, Voigt JH, Nicklaus MC, Winslow HE, Zhao H, Turpin JA, Yi J, Skalka AM, Burke TR, Jr., Pommier Y (2002) Metal-dependent inhibition of HIV-1 integrase. J Med Chem 45: 5661-5670

23. Andrake MD, Skalka AM (1995) Multimerization determinants reside in both the catalytic core and C terminus of avian sarcoma virus integrase. J Biol Chem 270: 29299-29306

24. Bojja RS, Andrake MD, Weigand S, Merkel G, Yarychkivska O, Henderson A, Kummerling M, Skalka AM (2011) Architecture of a fulllength retroviral integrase monomer and dimer, revealed by small angle X-ray scattering and chemical cross-linking. J Biol Chem 286: $17047-17059$
25. Boija RS, Andrake MD, Merkel G, Weigand S, Dunbrack RL, Jr., Skalka AM (2013) Architecture and assembly of HIV integrase multimers in the absence of DNA substrates. J Biol Chem 288: 7373-7386

26. Hare S, Gupta SS, Valkov E, Engelman A, Cherepanov P (2010) Retroviral intasome assembly and inhibition of DNA strand transfer. Nature 464: 232-236

27. Yin Z, Shi K, Banerjee S, Pandey KK, Bera S, Grandgenett DP, Aihara $\mathrm{H}$ (2016) Crystal structure of the Rous sarcoma virus intasome. Nature 530: 362-366

28. Ballandras-Colas A, Brown M, Cook NJ, Dewdney TG, Demeler B, Cherepanov P, Lyumkis D, Engelman AN (2016) Cryo-EM reveals a novel octameric integrase structure for betaretroviral intasome function. Nature 530: 358-361

29. Peletskaya E, Andrake M, Gustchina A, Merkel G, Alexandratos J, Zhou D, Bojja RS, Satoh T, Potapov M, Kogon A, Potapov V, Wlodawer A, Skalka AM (2011) Localization of ASV integrase-DNA contacts by site-directed crosslinking and their structural analysis. PLoS One 6: e27751

\section{Sukcesy i wyzwania na polu badan enzymów retrowirusowych Anna Marie (Ann) Skalka $₫$, Mark D. Andrake, Richard A. Katz}

Fox Chase Cancer Center, Institute for Cancer Research, Temple University Health System, Philadelphia PA, USA

ఐe-mail: AM_Skalka@fccc.edu

\section{STRESZCZENIE}

Współpraca między zespołami badawczymi profesora dr. Wlodawera i dr Skalki trwa od niemal 30 lat. W tym czasie obie grupy opublikowały wspólnie 18 prac, w tym kilka bardzo często cytowanych artykulów w czasopismach naukowych, rozdziałów książek oraz recenzji prac przeglądowych. Ogromnie cieszymy się z możliwości dzielenia się entuzjazmem, wiedzą i doświadczaniem z naszymi Kolegami z Frederick, a także z długoletniej przyjazni, jaką się darzymy.. 